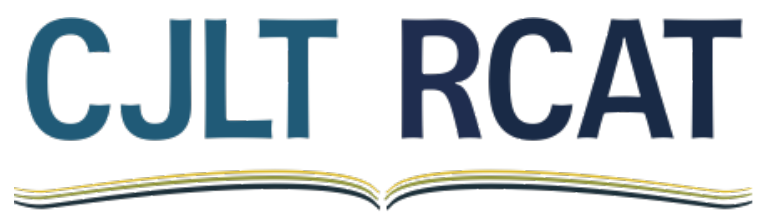

Canadian Journal of Learning and Technology

La Revue canadienne de l'apprentissage et de la technologie

\title{
When You Come to a Fork in the Road, Take It: Teaching Social Work Practice Using Blended Learning
}

\section{Si une deuxième voie s'offre à vous, prenez-la ! Enseigner la pratique en travail social à l'aide d'apprentissages mixtes}

\author{
Catherine de Boer, Memorial University of Newfoundland \\ Sandra Loucks Campbell, Renison University College at the University of Waterloo \\ Angela Hovey, Pace Consulting Group, Pace Homecare, Pace Physiotherapy
}

\begin{abstract}
The debates surrounding the effectiveness of teaching social work online highlight the challenges of adequately preparing students for face-to-face practice by way of web-based technologies. The purpose of this paper is twofold. Firstly, to briefly describe how a particular School of Social Work when designing its part-time undergraduate degree program (BSW), arrived at a fork in the road and instead of choosing between the paths of in-class or online course delivery, the School decided to offer the entire degree using a blended learning platform. Secondly, to compare the development and implementation of three specific practice courses within the part-time degree program (interviewing and assessment, social work theory, and a practicum integration seminar) each of which was offered using blended learning. This paper contributes to the debate about the value of using net-based technologies when teaching social work practice and will be helpful to educators from within many disciplines, who are wishing to critique their own development processes when designing and teaching practice courses using blended learning.
\end{abstract}

\section{Résumé}

Le débat sur l'efficacité de l'enseignement du travail social en ligne éclaire les difficultés d'une préparation adéquate des élèves à des entretiens face à face effectués par visioconférence.

L'objectif de ce rapport est double : en premier lieu, décrire rapidement comment, placée devant un choix difficile lors de la conception de son programme d'études de premier cycle, une École de travail social, au lieu de choisir entre un cours donné en classe ou en ligne, a décidé d'offrir le cours complet au moyen d'un programme d'apprentissage mixte; en second lieu, comparer la création et la mise en place, dans le cadre du programme universitaire à temps partiel, de trois cours pratiques (entrevue et évaluation; théorie du travail social; et séminaire d'intégration des 
travaux pratiques) offerts en apprentissage mixte. Ce rapport participe au débat sur la valeur de l'utilisation des applications du Web pour enseigner la pratique en travail social; il servira aux éducateurs de nombreuses disciplines qui souhaitent faire la critique de leurs propres processus de perfectionnement lorsqu'il s'agit de concevoir et de donner des cours pratiques en apprentissage mixte.

\section{Introduction - Arriving at the Fork in the Road}

Our School of Social Work had successfully offered a full-time Bachelor of Social Work (BSW) program for many years when in the early 2000's, a part-time program was considered. The School is situated within a university that is world renowned for its co-operative education, and distance education (DE) programs and hence, we were in an ideal milieu for considering webbased technologies for social work course delivery. The full-time BSW was an intensive ten month post degree program delivered exclusively on campus that predominately attracted recent graduates who were in their early 20's and entering their first career. The part-time BSW was expected to attract students who were older and who had more experience with social work practice, but less experience with technology than "typical" university students. It was suspected that applicants would already be working in demanding social work roles, such as child welfare and residential mental health treatment centres, but were now seeking a BSW to enhance their qualifications and improve their career trajectories. It was anticipated that most would continue to work full time and/or balance family responsibilities while in the program and hence would require flexible course offerings. It seemed unrealistic to offer the part-time program exclusively on campus in traditional in-class venues. We had arrived at a fork in the road. How could we make the part-time program accessible to non-mainstream students using off campus online course delivery without compromising their practice skill development and the overall effectiveness of the BSW program?

\section{Literature Review}

\section{Online versus In-class Debate}

Before we explore the literature it might be best to provide a working definition of online learning. Although we acknowledge web-based components can be incorporated into the classroom, in this paper online learning refers to course content and instruction being delivered off campus via the internet. In university settings online learning is typically administered using a learning management system (LMS), such as Blackboard Inc., WebCT, or Desire2Learn. A variety of net-based technologies, such as asynchronous chat forums, blogs, Elluminate, Skype and audio and video links can be used when delivering courses online.

The literature is replete with rationales for selecting either online or in-class course methods for social work course delivery. On the one hand, off campus online education is viewed as an ideal mechanism for increasing the accessibility of social work programs (Alonso, López, Manrique, \& Viñes, 2005; Brand, 1995; Petracchi, Mallinger, Engel, Rishel, \& Washburn, 2005), which is in keeping with the social work values of inclusion and empowerment. There is evidence that "students now more than ever before are juggling multiple responsibilities of study, working in paid employment and providing child and/or parental care" (McInnis, James, \& Hartley, 2000, as 
cited in Maidment, 2005, p. 186). Like many educational institutions, we were also looking to off campus online course delivery as a means of meeting the needs of this new demographic.

On the other hand, schools of social work are charged with the responsibility to prepare students for effective social work practice, and we wondered if off campus and online course delivery would help us achieve that objective. As Petracchi et al. (2005) observed,

The development of communication skills, the mentoring relationship between professor and student, and the expansion of critical thinking ability are believed to be the essential aspects of the social work student's socialization ... [and] traditionally, social work educators have believed fostering interaction between the professor and student and among peers could be accomplished solely through the conventional classroom formats, with face-to-face interactions. (p. 300)

The comfort with face-to-face course delivery reflected in the above quotation coupled with reservations about adopting online courses were factors in our decision-making.

Moore (2005a) considers these reservations typical. He conducted a nationwide survey in the U.S. of social work faculty with web-based teaching experience, regarding their perceptions of the effectiveness of the modality. For the purposes of the survey, web-based instruction was defined as " $50 \%$ of the course content offered via the web" (p. 57-58). Faculty perceived in-class to be more effective than web-based instruction in all curriculum areas. However, the extent of the perceived effectiveness varied. Policy courses were viewed as the most effective when delivered via the web and practice and field courses were the least. Additionally, Faux and Black-Hughes (2000) concluded that a social work history course using traditional lectures and discussion was superior to internet-only instruction, which consisted of access to specific web pages, electronic assignments and self-administered worksheets. Likewise Faul, Frey and Barber (2004) discovered that a traditional social work research methods course produced overall better "knowledge gain" (p. 115) than its web-assisted counterpart. In this study the "web-assisted" course used the "internet as a resource" (p. 106) with students" class time remaining the same as the traditional course.

Other studies suggest online courses are more effective. Bushfield (2005), for example, concluded that a field integration seminar "with asynchronous, online participation in regular discussion topics and specific assignments" (p. 219) had a higher rate of student satisfaction, a greater depth of discussion, and improved integration of learning among students compared to the in-class counterpart. Owston (2000) when comparing academic achievement and satisfaction between courses offered face-to-face, correspondence courses using traditional print correspondence modes and online courses that included weekly study schedules, readings, lecture notes, graphics and electronic discussion rooms, discovered that the online courses had greater dropout rates but students who completed had significantly higher grades than students who took the identical course in-class.

To add to the confusion, there are also studies that suggest there is no significant difference in effectiveness between in-class and web-assisted teaching methods (Faul, Frey, \& Barber, 2004; Petracchi et al., 2005). Likewise Hisle-Gorman and Zuravin (2006) conclude "quantitative studies are split in their findings of the effectiveness of online and traditional instruction" (p. 79$80)$. 
This lack of clarity with respect to the efficacy of online courses has led some (e.g., Maidment, 2005; Petracchi et al., 2005) to avoid positioning themselves in either a face-to-face, in-class or an exclusively online teaching camp. Similarly, our School's eventual decision to offer our parttime BSW using blended learning (defined below) reflects our intention to neither ignore the benefits of online education nor embrace them unequivocally. However, we were challenged, as Maidment (2005) suggests, by the need to strike a "balance between harnessing the promise offered by online delivery of education, while ensuring students are not disadvantaged through this method of learning" (p. 186).

The literature certainly speaks of "the promises" of online education. In addition to increasing accessibility, Alonso et al. (2005) credit "computers as the saviours of the educational system ... [because they can] personalize learning" (p. 218), allowing education to be tailored to a student's level of understanding and needs. Online learning is also viewed as a vehicle to increase student participation and engagement. Students cannot be "passive recipients of information" (Maidment, 2005, p. 189) doing "seat time" (Macy, Rooney, Hollister \& Freddolino, 2001, p. 70) but rather must actively engage with the material in ways that can be monitored and evaluated. It is also suspected, although as yet unproven, that students taking online courses have increased comfort with technology, which can help them utilize the technologies used in social work practice (Moore, 2005; Petracchi et al., 2005).

However, the literature also speaks of the disadvantages of online education, including the potential loss of the social dimensions of learning. Constructivist pedagogies stress the importance of learning environments (Vygotsky, 1978). According to Moore (2005b), "constructivists believe the world is constructed in the mind and personal constructions define personal realities" (p. 18). It is believed individuals learn best in community; when they feel connected to their classmates, their instructor, and the material itself (Herie, 2005). Advances in technology are coinciding with changes in our understandings of how knowledge is created and how learning is facilitated. Ironically, at the same time that schools of social work are understanding knowledge as being created within a community of knowers (Paré, 1995), we are moving towards online offerings that provide students with little to no direct contact with their fellow knowers. Concerns about faceless teaching (Berge, 1998; Kim, 2005) and student isolation (Herie, 2005) are particularly alarming for social work educators, who seek to prepare students for a skills-based, interactive, and interpersonal profession but are using a modality that has these same students sitting alone behind computer monitors.

Madoc-Jones and Parrott (2005) attribute student isolation to the replication of traditional teaching methods via an online medium. In these situations, technology replaces face-to-face contact and students become disengaged from the learning process. In a similar vein, Maidment (2005) refers to the "wholesale dumping" of lecture notes and tutorial materials onto the web as a "lazy approach to delivering education" (p. 189) that can leave students feeling angry and resentful. Likewise, Mason (1998) is disparaging about the content and support method of online teaching, which involves downloading class material in print form, delivering it online with support being offered in the limited forms of email and computer conferencing. In all these scenarios, the potential of online teaching is not realized.

In this regard, Bikowski (2007) suggests we broaden the concept of "learning community" to include the dialogue students can initiate and the relationships they can form using the internet. Internet dialogue can be supplemented with phone calls and other activities, which have "more 
social presence" (Bikowski, 2007, p. 138). Online instructors can help create a learning community by providing frequent feedback and encouraging students to give and receive feedback from each other using mechanisms such as electronic bulletin boards and blogs. A blended learning approach, as we discuss below, can also prevent student isolation while maximizing the advantages of online teaching.

\section{Blended Learning - Taking the Fork in the Road}

For the purposes of this paper, blended learning refers to the "thoughtful integration of classroom face-to-face learning experiences with online learning experiences" (Garrison \& Kanuka, 2004, p. 96). Although blended learning can refer to the augmentation of in-class teaching with various forms of net-based technology (such as embedding YouTube clips into power point presentations, or having student complete online quizzes) with the primary setting being the class room, in this paper the term refers to teaching that takes place primarily online with the addition of face-to-face components, which in our case included on-campus workshops.

There are many rationales schools of social work could use for adopting blended learning, not the least of which are improved teaching and learning outcomes (Owston, Wideman, Murphy, \& Lupshenyuk, 2008). The Program in Course Redesign sponsored by the Pew Charitable Trust Foundation (Twigg, 2003), for example, reported "improved student learning" in twenty of the thirty courses that were restructured using technology (p. 30). Other positive outcomes included "increased course-completion rates, improved retention, better student attitudes toward the subject matter and increased student satisfaction with the mode of instruction" (p. 30). Since 1997, the University of Central Florida, a pioneer in the field of technology-mediated instructional delivery, has been collecting and analysing data on their blended learning offerings. They have consistently found "higher levels of student and faculty satisfaction, student learning outcomes that are higher than in comparable face-to-face and fully online courses, and high student demand because of increased convenience and flexibility" (Dziuban, Hartman, \& Moskal, 2004, p. 3). Owsten, Garison, and Cook (2006) noted an increase in the interaction between the instructor and students in blended versus traditional lecture style courses. Faculty reported they got to know their students better as individuals. Likewise increased student participation observed by Dziuban et al. (2004) was seen to increase "student (and probably instructor) information literacy" (p. 3). There are also pedagogical advantages to blended learning as students are presented with variety in instructional media enabling them to "utilize their most effective ways of learning" (Dede, 2000, p. 15, as cited in Albrecht, 2006, p. 5).

Although we were particularly encouraged by the above research, we continued to wonder if practice skills, such as interviewing, assessment, critical thinking, and theory application could be effectively taught using blended learning. Blended learning is often touted as "the best of both worlds," yet as Graham (2009) warns, blended learning environments can also "mix the least effective elements of both worlds" (p. 8). Much of the literature indicates that the benefits of blended learning are contingent on good design (Garrison \& Vaughan, 2008; Graham, 2009), yet there is little design information in the literature specific to skill-based learning and evaluation. At times, we felt we were mapping new territory with respect to course design and potentially filling a gap in the literature with respect to the application of blended learning to professional education in general and specifically to social work. 


\section{Three Examples of Blended Learning for BSW Practice Courses}

As our learning was cumulative, each of us building on the successes and learning gained from the design of the previous course (or courses), the remaining paper is organized chronologically with courses being presented in the order in which they were designed. Table 1, summarizes and compares various aspects of the respective courses and design processes.

\section{Course 1: Interviewing and Assessment for Social Work Practice Course Description and Context}

The interviewing and assessment course imparts theory and practice skills at micro, mezzo and macro levels. Using role plays, process recordings and specific assessment tools and strategies as instruments of learning, students are required to complete an individual assessment, a macro assessment exercise and a taped and analysed interview. Although teaching assessment online poses its own challenges, the challenging design aspects for the course described below concern teaching the interviewing components.

\section{Developmental Process and Challenges}

Teaching the "art" of interviewing online.

For many years interviewing, and to a lesser degree assessment, have been defined as part science and part art (Klein \& Bloom, 1995; Martinez-Brawley \& Zorita, 1998). As MartinezBrawley and Zorita (1998) argue, because of the nature of practice, social work has at times been located at the "edges of scientific discourse" (p. 197). They describe social work as a "collage" of overlapping elements of art and science where "intuitive reflection" is valued (p. 197). Their argument should not be seen as weakening the scientific nature of social work but rather, a call for our parallel attention to the art of practice.

Certain elements of the skill base are embedded in the personalities and life experiences of practitioners (Perlman, 1979). Although the science aspects might be successfully taught face-toface using lectures and targeted readings, these strategies are not ideal for teaching the art of interviewing. The challenge was how to teach the soft, more inaccessible material, the art, using technology.

Learning tools and course content needed to complement each other in the creation of a learning environment wherein each objective could be achievable and demonstrable. Course developers from the Centre for Extended Learning, with advanced familiarity of internet and software capabilities worked with the instructor to build learning tools, such as digital film clips, audio enhanced and timed PowerPoint presentations and graphics, computerized study guides and quizzes and asynchronous discussion groups, to attain the course learning objectives and to teach the art of interviewing using technology.

The course, both in class and online, included objectively defined elements such as "to gain an understanding of effective interviewing and communication concepts and skills" and "to demonstrate effective interviewing and communication skills in mock interviews." However, the course also included objectives related to the art of social work practice such as "to appreciate the usefulness of reflection in professional and personal growth, particularly in relation to one's own work" and to "use a reflection lens in analysing one's own work in interviewing and 
assessment processes." These art related objectives are embedded in the online iteration of the course through specific vignette reflection activities described below.

Designing online opportunities for students to observe, evaluate and practice interviewing skills.

For this course, a multi-step interview assignment was developed by the instructor, which was applied to posted video clips of 1) an ineffective individual interview, and 2) an effective individual interview (an improved version of the ineffective interview). Course participants were to view the ineffective interview first. Following posted guidelines prepared by the instructor, students reflected on their responses to the ineffective interview and subsequently posted their comments on an asynchronous, text-based discussion board, which was part of the learning management system. They then viewed a second posted video clip in which the interviewee described her experiences of the ineffective interview. Finally, students viewed a third posted video of the instructor providing an analysis of the interview. Students were only able to access the later stages in the process (the second and third posted videos) once they had completed the earlier stages (first and second posted videos). We came to refer to this assignment as a "required post." Students were required to post a summary of their own reflections before they gained access to the next video clip. The multiple steps within the assignment required students to personally reflect on the videos and take risks by sharing their views before they had the benefit of hearing the responses of classmates or the instructor. This process was repeated with the effective interview. At the end of the effective interview students were provided with an online version of the video that included tags identifying the specific interviewing skills being used. This video allowed students to review the skills in the interview as often as they wished. These interviews integrated the objective "science" of interviewing with the subjective "art," both important aspects of social work practice.

After all the interview segments were completed online, students were required to attend an intensive on campus weekend designed to help them develop and practice their skills face-toface. Four modules were covered during the course of the weekend, representing one third of the twelve module course.

\section{Implications for Blended Learning Design}

Initially students had trouble accessing all the segments of the interview assignment. The glitch, caused by a recent upgrade to the learning management system platform was amplified by students' feelings of their own technological inadequacy and ultimately prevented them from immediately contacting either technical support or the instructor. Glitches, such as these, are common in online course delivery and highlight the need for instructors to give explicit instructions to students and encourage them to immediately seek guidance when they run into technological problems. Students need to know that they are not being graded on their technological savvy and asking for help in this area will not compromise their social work skill development or their reputation with the teacher. As teachers, we can acknowledge our own discomfort or challenges with technology and thereby give students permission to do the same. 


\section{Course II: Selected Theories for Social Work Practice: Analysis and Application}

\section{Course Description and Context}

The second course, a theory course, focuses on the analysis and application of selected theories and practice methods considered foundational to generalist-eclectic practice. The course introduces the student to essential features of selected theories used in social work, including the historical development, underlying premises regarding the source of human problems and solutions, the nature of the helping role, and associated assessment and treatment skills. One third of the course is devoted to making the theories come alive through case studies, video clips, and role plays. A key feature of the course includes the development of critical thinking skills considered essential in the effective selection and application of theory to client situations.

\section{Developmental Process and Challenges}

\section{Structuring and organizing the course}

Loosely following Turner's (2002) guidelines pertaining to the essential theories used in social work practice, seven categories of theory were selected and covered in the course. After an introductory module designed to help the students place the selected theories within the framework of generalist-eclectic practice, the seven categories of theory were evenly distributed among the remaining five modules. The course concluded with one full day, face-to-face workshop focused entirely on developing skills needed for critical thinking and theory application.

\section{Making content interesting and retainable}

Two student reference tools were developed for each theory. These tools were: 1) a map visually depicting the developmental logic and uniqueness of the theory and, 2) a table with common headings (e.g., main characteristics, understanding of human problems, understanding of solutions, assessment tools, interventions, nature of the helping role, and strengths and weaknesses) to describe each theory. The rationale for this rests on the assumption that students will be able to see a specific theory within a larger theoretical corpus would increase students' understanding. Rather than viewing each theory in isolation, they could begin to see the similarities and differences between them and appreciate how each theory was held together by an internal logic and consistency. This could ease understanding and help students retain the information. It was reasoned that presenting the same content in multiple forms (e.g., maps, tables, graphics, audio-taped lectures, and assigned readings) would create more pathways for retention and would ensure that the same information was accessible to students with various learning styles.

Another strategy employed to increase interest was to break each lecture down into small topical segments ranging in length from 3 to 15 minutes. Each segment was accompanied by timed visuals, which created interest. The lectures were audio recorded in the order in which they were to be presented in the course. This enabled the instructor to refer in each lecture to content presented in previous lectures. The required readings and assignments were woven into the lectures. It was reasoned that the more connections students could make between the materials, the greater the chance of retention.

\section{Developing critical thinking skills}


Critical thinking is essential for theory appraisal and application (Gambrill, 2000; Mumm \& Kersting, 1997). In an in-class course taught previously, an exercise called the Triple-Entry Notebook (TEN) was used. This exercise was originally designed by Kooy \& Kanevsky (1997) to help students critically evaluate assigned readings within an in-class setting. In the instructor's translation of the exercise for online use, students were randomly assigned to groups of three, each with their own asynchronous, text-based discussion board that was accessible only to them and the instructor. Students would read a case study profiling a particular theory being applied to a practice situation after which they would prepare two notebook entries. The first entry consisted of a summary of the case. The second entry consisted of the student's reflections about the case and the theory application. In this second entry, students needed to move beyond content to formulate their own reactions and express their thoughts and understandings. They would then post both entries on the discussion board, by a specific deadline. The discussion board was set up such that the group members could not see each other's entries until all entries were posted. After the first two entries were posted by all of the group members, students completed their third entries by commenting on each of their group member's notebooks. They completed the assignment by engaging in an online discussion.

\section{Creating a community of learners}

It was intentional that students be provided with occasions to dialogue with each other using an asynchronous, text-based discussion board, entitled Student Discussion Forum as well as occasions to dialogue with the instructor using a separate discussion board. Three of the modules had exercises associated with them that required students to post their completed assignments on these discussion boards and to respond to each other's postings. The TEN exercise gave students the opportunity to interact with the members of their small group in a rich and in depth way. Several students chose to increase their social presence (Bikowski, 2007) with each other by exchanging personal contact information so as to discuss readings, course content and assignments over the telephone, through personal email, or by MSN. This was not an expectation but students indicated it was helpful.

\section{Implications for Blended Learning Design}

The TEN exercise produced strong reactions. Some loved it. Others were frustrated because students in their group did not post their entries on time, slowing the process for everyone. Some students would post comments that were trite or unperceptive, such as "I loved this reading" or "I agree with this author." These types of comments posed problems for their group members who were expected to use these comments to push their own learning. In the future, a tighter description of instructor expectations for this format of posting is recommended, perhaps even providing examples of what the instructor considers quality posts. For example, a quality post could include taking a position either in reaction to or in support of the material and defending the position with examples from one's practice or outside readings. A quality post could also involve some reasoning or analysis of one's response to the article and ideally would evidence critical and reflexive thinking.

The pedagogical strength of the course was the weaving in of content from the textbook, the maps and tables, and the lectures and the making of connections between the theories, readings, and visuals. This ran at cross-purposes with the need to build a course that could be offered multiple times for many years. Curriculum and course content changes, textbooks are revised 
and old editions are no longer available, and theories are dynamic. In this case, content could not be added or removed to accommodate these changes without compromising the flow and organization of the course. In the future, designing standalone modules that can be removed or added as needed is recommended. Refraining from making direct references to the textbook in the audio taped lectures is also recommended.

\section{Course III: Integration Seminars}

\section{Course Description and Context}

The Integration Seminar is comprised of three credits and runs concurrently with the field placement. The goal of the seminar is to process and integrate theoretical social work knowledge with field experiences. To that end, the course structure mirrors the field placement. It begins with the development of a learning contract, moves through the various stages of the helping process, and concludes with the topics of evaluation and saying goodbye to the placement and the people served.

Part-time students begin their placements at different times and progress through the modules at different paces. The modules have been developed to facilitate the turnstile nature of the seminars. Students enter the seminar at various points in the BSW program, yet they follow a similar progression and task completion schedule thereby ensuring consistent content delivery and learning opportunities. Each module includes an open-ended forum for students to discuss field experiences within the theoretical focus of the module in order to benefit from facilitated peer supervision. It is expected that each student make meaningful contributions in each module and provide feedback to any other student postings. Each student is also required to attend one face-to-face meeting for each course credit and prepare a case presentation for at least one of these face-to-face meetings. The number of students enrolled in the seminar at any given time ranged between two and twenty.

\section{Development Process and Challenges}

The greatest challenge for this course was establishing and maintaining needed interactive components within the seminar. Given the turnstile entry and exit points, there was substantial risk of students not feeling part of their community of learners as its membership was constantly changing. As a result students could experience isolation, a lack of meaningful interaction, and a lack of support from their peers or the seminar facilitator. The pace for completion of each seminar dovetailed with the rate at which the student completed their placement hours. Some students were able to complete their placements in a short and intensive block while others would devote five to ten hours per week to their placements stretching them out over a one to two year period. This demanded incredible flexibility in setting assignment deadlines and developing other time sensitive components within the seminar. In addition, instructor preference was to use interactive teaching methods such as student initiated discussions and small group exercises rather than lecturing. Thus, the development of the online Integration Seminar required the rethinking of interactive learning experiences using a dynamic virtual peer support model that attempted to mirror face-to-face peer support with the online written interactions.

Part-time students have many compelling and competing demands including work, family responsibilities, and their studies, which led them to minimally engage in online discussions. 
Their interaction resembled the maypole style of communication, with students posting their points and the instructor response being the only thread in their initial posting (Toseland \& Rivas, 2005). Thus, the postings appeared to be primarily between the student and instructor, lacking the intended peer support component.

The challenge for students was taking the time to create thoughtful postings and schedule the face-to-face component each semester. Often they read many of the postings and learned tremendously from their peers but did not craft responses. It appeared that those who posted did not seem to have a sense that others were reading their posts with the exception of the instructor - as the instructor responded to the posts in a timely manner. Some found the technology difficult to navigate and identified a strong preference for the face-to-face version of a seminar. Some arrived at their mid-placement evaluation without having made a single posting and needed to be reminded of this course requirement. Scheduling the face-to-face meetings was difficult as students had busy schedules and some lived far from campus. These issues made it difficult for the instructor to be a facilitator of learning - moving the instructor role to that of an administrator who actively monitors the completion of all course requirements, schedule and coordinate meetings, and take attendance.

\section{Implications for Blended Learning Design}

A process for eliciting more interactive discussion is still needed. Simply imposing a required number of postings runs at cross-purposes with a natural organic discussion and exploration. Although the students were appreciative of the timely and thorough responses to their posts by the facilitator, they were disappointed with the lack of peer interaction. This dilemma presents an ongoing challenge for the instructor who prefers to be a discussion facilitator rather than an administrator. Students continue to report that the face-to-face component is beneficial to their learning; however, scheduling these components remains a challenge. Likewise, planning the length of the meeting is difficult because student presentations at these meetings are a course requirement and the fluctuations in class size means that the number of students that are required to complete the case presentation component at a particular meeting varies.

Table 1: Summary and Comparison of Blended Learning Courses

\begin{tabular}{|l|l|l|l|}
\hline & \multicolumn{1}{|c|}{ Theories Course } & \multicolumn{1}{|c|}{$\begin{array}{c}\text { Interviewing and } \\
\text { Assessment }\end{array}$} & \multicolumn{1}{|c|}{ Integration Seminars } \\
\hline $\begin{array}{l}\text { Type of } \\
\text { Course }\end{array}$ & $\begin{array}{l}\text { Content based course } \\
\text { with practice } \\
\text { applications }\end{array}$ & $\begin{array}{l}\text { Interactive skill } \\
\text { development course }\end{array}$ & Seminar \\
\hline $\begin{array}{l}\text { Course } \\
\text { Objective } \\
\text { application of practice } \\
\text { theories }\end{array}$ & $\begin{array}{l}\text { Development and } \\
\text { evaluation of } \\
\text { interviewing and } \\
\text { assessment skills at } \\
\text { micro, mezzo, and } \\
\text { macro levels }\end{array}$ & $\begin{array}{l}\text { Integration of social work } \\
\text { knowledge with field } \\
\text { experiences }\end{array}$ \\
\hline Design Foci & $\begin{array}{l}\text { - Structuring and } \\
\text { organizing the course } \\
\text { in Making content } \\
\text { interesting and }\end{array}$ & $\begin{array}{l}\text { Teaching the "art" } \\
\text { of interviewing online } \\
\text { Creatively linking } \\
\text { specific learning }\end{array}$ & $\begin{array}{l}\text { - Establishing and } \\
\text { maintaining interactive } \\
\text { components given the turnstile } \\
\text { entry and exit of students }\end{array}$ \\
\hline
\end{tabular}




\begin{tabular}{|c|c|c|c|}
\hline & Theories Course & $\begin{array}{c}\text { Interviewing and } \\
\text { Assessment }\end{array}$ & Integration Seminars \\
\hline & $\begin{array}{l}\text { retainable } \\
\text { - Developing } \\
\text { critical thinking skills } \\
\text { online } \\
\text { - Creating a } \\
\text { community of learners }\end{array}$ & $\begin{array}{l}\text { objectives with online } \\
\text { teaching methods } \\
\text { - Designing online } \\
\text { opportunities for } \\
\text { students to observe, } \\
\text { evaluate, and practice } \\
\text { interviewing skills }\end{array}$ & $\begin{array}{l}\text { - Creating flexible } \\
\text { assignment deadlines } \\
\text { - Creating a virtual peer } \\
\text { support community of learners }\end{array}$ \\
\hline $\begin{array}{l}\text { Online } \\
\text { Components }\end{array}$ & $\begin{array}{l}\text { - } \quad \text { Audio-taped } \\
\text { lectures with visuals } \\
\text { - Theoretical maps } \\
\text { and charts } \\
\text { - Discussion Boards } \\
\text { - Triple Entry } \\
\text { Notebook Exercise } \\
\text { (adapted for online } \\
\text { use) } \\
\text { - Video of theories } \\
\text { being applied in a } \\
\text { therapy session }\end{array}$ & $\begin{array}{l}\text { - } \quad \text { Audio-taped } \\
\text { lectures with visuals } \\
\text { - Multi-stage } \\
\text { interview assignment } \\
\text { with } \text { Required Posts } \\
\text { - } \quad \text { Discussion boards }\end{array}$ & $\begin{array}{l}\text { - Course content - topical } \\
\text { modules, reading assignments, } \\
\text { and links to supplementary } \\
\text { readings } \\
\text { - Open-ended online } \\
\text { discussion forums for each } \\
\text { module }\end{array}$ \\
\hline $\begin{array}{l}\text { Face-to-face } \\
\text { components }\end{array}$ & $\begin{array}{l}\text { One full day "theory } \\
\text { application" workshop } \\
\text { representing one } \\
\text { module }\end{array}$ & $\begin{array}{l}\text { An intensive weekend } \\
\text { designed for skill } \\
\text { development and } \\
\text { practice representing } \\
\text { four modules }\end{array}$ & $\begin{array}{l}\text { One face-to-face group } \\
\text { meeting several hours in length } \\
\text { per term }\end{array}$ \\
\hline $\begin{array}{l}\text { Ratio of } \\
\text { face-to-face } \\
\text { to online } \\
\text { components }\end{array}$ & 1 to 6 & 1 to 2 & Approximately 1 to 4 \\
\hline $\begin{array}{l}\text { Design } \\
\text { Triumphs }\end{array}$ & $\begin{array}{l}\text { - Downloadable } \\
\text { theoretical maps and } \\
\text { charts } \\
\text { - Short lecture } \\
\text { segments with visuals } \\
\text { - Critical thinking } \\
\text { exercises }\end{array}$ & $\begin{array}{l}\quad \text { Clear course } \\
\text { objective linked to } \\
\text { specific online } \\
\text { teaching tools } \\
\text { - Multi-step } \\
\text { interview assignment } \\
\text { with required post } \\
\end{array}$ & $\begin{array}{l}\text { - Module content was } \\
\text { engaging and effective with } \\
\text { flexibility to meet student } \\
\text { learning needs } \\
\text { - Discussion boards were } \\
\text { associated with each module } \\
\text { for ease of posting }\end{array}$ \\
\hline $\begin{array}{l}\text { Implications } \\
\text { for } \\
\text { improvement }\end{array}$ & $\begin{array}{l}\text { - Explicitly state } \\
\text { expectations for } \\
\text { postings with respect } \\
\text { to depth and quality } \\
\text { - Create stand-alone } \\
\text { modules that can } \\
\text { easily added or } \\
\text { removed }\end{array}$ & $\begin{array}{l}\text { - Technological } \\
\text { glitches need to be } \\
\text { reported immediately } \\
\text { to save time and } \\
\text { frustration. }\end{array}$ & $\begin{array}{l}\text { - Continue efforts to } \\
\text { increase student interaction } \\
\text { - Create an evaluation } \\
\text { process that maintains student } \\
\text { anonymity } \\
\text { - Decrease administrative } \\
\text { functions of the instructor and } \\
\text { increase group facilitation role }\end{array}$ \\
\hline
\end{tabular}




\section{Discussion and Conclusion}

As evident from Table 1, we approached the development of our respective courses with our unique questions and design challenges. Although each course was considered a practice course, they varied with respect to type (e.g., content focused, skills-based, or seminar format), course objectives and the ratio of content versus practice skill development opportunities. Moreover, we each had distinctive teaching experiences, particular preferences for and suitability to various teaching methods and our own strengths and biases. That said, we were surprised by the number of experiences we shared. For example, we all struggled with how to encourage and measure student involvement, teach and model practice skills online, and build an effective community of learners online. While we conclude there is no single correct way to design a blended course (Garrison \& Vaughan, 2008; Graham, 2009), our common challenges lead to insights that may prove beneficial to other social work academics designing such courses.

Each of us had experience teaching social work practice courses in traditional in-class settings. Consistent with the literature (Madoc-Jones \& Parrott, 2005; Maidment, 2005), we soon discovered that many of our in-class methods could not be replicated online or creativity was required in translating them to online methods. We felt like travellers discovering the language and customs of our homeland held little meaning and efficacy in the country we were now visiting. This traveller metaphor enabled us to shift our approach. Rather than try to replicate our in-class teaching methods, we tried to translate them. For example, the instructor for Course I had success working with the course developers and technical support people at our university, who helped translate her in-class teaching ideas into methods and activities that would work online. For Course III, the instructor's interactive teaching methods were translated into a webbased peer support model that attempted to mirror face-to-face peer support with the online written interactions. Exercises such as the required posts, which cannot be done in a class setting, allowed us to experiment with new teaching methods unavailable to us "back home." We also discovered that the more transparent our pedagogy and more explicit our learning objectives, the less likely the material would be lost in translation.

The traveller metaphor also helped us understand some of the challenges we faced in encouraging student participation and building online learning communities. For example, one instructor was initially baffled when stimulating content posted online elicited little to no reaction from students. Yet, in the face-to-face seminars, students provided insightful and thought-provoking oral responses. We began to understand that some students were experienced and hence comfortable using information and communication technologies (ICT) such as texting, emailing, blogging, and posting things on facebook or YouTube. Others were not as experienced or comfortable. They too were like travellers, unfamiliar with the language and methods of the online world. We reasoned even the best designed online course filled with enticing content would fail to produce quality dialogue from these technological tourists if their language barriers were not addressed. It may be that problems, such as these, will diminish over time as more people gain access to and familiarity with advanced ICT. In the interim, we may need to build acculturation opportunities into our courses.

If we really are dealing with two different worlds or paths - the path of face-to-face teaching and the online path - a troubling question arises. Had we come full circle, asking ourselves again whether social work practice can or should be taught online? In social work, the abilities to develop relationships and communicate are essential skills. Thus, it was alarming when we 
discovered that the online relationships between students seemed weak and superficial (see for example, Course III struggles to have students engage in discussions with each other or contribute meaningfully in group assignments). The apparent weakness in building online relationships and dialoguing with each other could have indicated that these students had weak face-to-face skills or that it was merely their computer literacy and functionality that was weak. Had we developed a strictly online curriculum for our part-time program, we might have evaluated the practice skill development of these students unfairly. But instead, we had a renewed confidence that the decision to offer the part-time program using a blended learning approach was indeed the right one. We were able to use the face-to-face sessions to facilitate and evaluate the student's abilities to transfer practice skills taught online to the "real world" and to determine if the nature and quality of students' online communications was reflective of their skills or not. Ultimately, we were able to ensure the learning we had desired had indeed taken place and that the students' practice skills were being evaluated fairly.

We noticed that the concerns in the literature about faceless teaching (Berge, 1998; Kim, 2005) and student isolation (Herie, 2005) seemed to lessen as the blended learning approach to online teaching evolved. We also noticed that as students become more technologically savvy, the benefits of online courses seemed to also be embraced. As instructors and course developers, we used our reflections on blended learning design as it relates to improvement to the blended learning courses. In our program, there is no longer a debate about offering any course online; however, we have come to the conclusion that blended learning offers an effective approach for practical social work courses.

\section{References}

Albrecht, B. (2006). Enriching student expereince through blended learning. EDUCAUSE Center for Applied Research Research Bulletin, 2006, 12, 1- 12.

Alonso, F., López, G., Manrique, D., \& Viñes, J. (2005). An instructional model for web-based e-learning education with a blended learning approach. British Journal of Educational Technology, 36(2) 217-235.

Berge, Z. (1998). Barriers to online teaching in post-secondary institutions: Can policy changes fix it? Online Journal of Distance Learning Administration, 1(2). Retrieved from http://www.westga.edu/ distance/ojdla/summer12/berge12.html

Bikowski, D. (2007). Internet relationships: Building learning communities through friendship. Journal of Interactive Online Learning, 6(1), 131-141.

Brand, M. (1995). The wise use of technology. Educational Record, 76(4), 39-45.

Bushfield, S, (2005). Field clusters online. Journal of Technology in Human Services, 23(3), 215-227.

Dziuban, C., Hartman, J. \& Moskal, P. (2004). Blended learning. EDUCAUSE Center for Applied Research, Research Bulletin, 2004, 7, 1 - 12. 
Faul, A., Frey, A. \& Barber, R. (2004). The effects of web-assisted instruction in a social work research methods course. Social Work Education, 23(1), 105-118.

Faux, T. \& Black-Hughes, C. (2000). A comparison of using the internet versus lectures to teach social work history. Research on Social Work Practice, 10(4), 454-466.

Gambrill, E. (2000). The role of critical thinking in evidence-based social work. In P. AllenMeares, \& C. Garvin, C. (Eds.), The Handbook of Social Work Direct Practice (pp. 4363). Thousand Oaks, CA: Sage.

Garrison, D. \& Kanuka, H. (2004). Blended learning: Uncovering its transformative potential in higher education. The Internet and Higher Education, 7(2), 95- 105.

Garrison, D. \& Vaughan, N. (2008). Blended learning in higher education: Framework, principles, and guidelines. San Francisco: Jossey-Bass.

Graham, C. (2009). Blended learning systems. In C. J. Bonk \& C. R. Graham (Eds.), The handbook of blended learning: Global perspectives, local designs (pp. 3-21). San Francisco: Pfeiffer.

Herie, M. (2005). Theoretical perspectives in online pedagogy. Journal of Technology in Human Services, 23(1), 29-52.

Hisle-Gorman, E. \& Zuravin, S. (2006). Teaching social work research: A comparison of webbased and in-class lecture methods. Journal of Technology in Human Services, 24(4), 7793.

Kim, H. (2005). "Can a faceless teacher be close to students?": The lived experience of online instructors in higher education (Ed.D. dissertation). Retrieved from Dissertations \& Theses: Full Text. (Publication No. AAT 3164996).

Klein, W., \& Bloom, M. (1995). Practice wisdom. Social Work, 40(6), 700-807.

Macy, J., Rooney, R., Hollister, C., \& Freddlino, P. (2001). Evaluation of distance education: Programs in social work. In J. Miller-Cribbs (Ed.), New advances in technology for social work education (pp. 63-85). Boston: The Haworth Press.

Madoc-Jones, I. \& Parrott, L. (2005). Virtual social work education - Theory and experience. Social Work Education, 24(7), 755-768.

Maidment, J. (2005). Teaching social work online: Dilemmas and debates. Social Work Education, 24(2), 185-195.

Martinez-Brawley, E., \& Zorita, P. M-B. (1998). At the edge of the frame: Beyond science and art in social work. British Journal of Social Work, 28, 197-212.

Mason, R. (1998). Models of online courses. ALN Magazine, 2, 2. Retreived from http://www.aln.org/alnweb/magazine/vol2_issue2/masonfinal.htm 
Moore, B. (2005a). Faculty perceptions of the effectiveness of web-based instruction in social work education: A national study. Journal of Technology in Human Services, 23(1), 5366.

Moore, B. (2005b). Key issues in web-based education in the human services: A review of the literature. Journal of Technology in Human Services, 23(1), 11-28.

Mumm, A., \& Kersting, C. (1997). Teaching critical thinking in social work practice courses. Journal of Social Work Education, 33(1), 75 - 84.

Owston, R. (2000). Evaluating web-based learning environments: Strategies and insights. CyberPsychology \& Behaviour, 3(1), 79-87.

Owston, R., Garrison, D., \& Cook, K. (2006). Blended learning at Canadian universities: Issues and practices. In C. J. Bonk \& C. R. Graham (Eds.), The handbook of blended learning: Global perspectives, local designs (pp. 338-350). San Francisco: Pfeiffer

Owston, R., Wideman, H., Murphy, J., \& Lupshenyuk, D. (2008). Blended teacher professional development: A synthesis of three program evaluations. Internet and Higher Education, 11, 201-210.

Paré, D. (1995). Of families and other cultures: The shifting paradigm of family therapy. Family Process, 34, 1-19.

Perlman, H. (1979). Relationship: The heart of helping people. Chicago: The University of Chicago Press.

Petracchi, H., Mallinger, G., Engel, R., Rishel, C., \& Washburn, C. (2005). Evaluating the efficacy of traditional and web-assisted instruction in an undergraduate social work practice course. Journal of technology in Human services, 2(3), 299-310.

Toseland, R. W. \& Rivas, R. F. (2005). An introduction to group work practice (5 ${ }^{\text {th }}$ Ed.). Boston, MA: Allyn and Bacon.

Turner, F. (2002). The theoretical bases of practice. In F. J. Turner (ed.), Social work practice: A Canadian perspective (pp. 46-56). Toronto: Pearson Education Canada, Inc.

Twigg, C. (2003). Improving learning and reducing costs: New models for online learning. EDUCAUSE Review, 38(5), 28-38.

Vygotsky, L. (1978). Mind in society: The development of higher psychological processes. Cambridge, MA: Harvard University Press. 


\section{Authors}

Catherine de Boer, Memorial University of Newfoundland. Email: cdeboer@mun.ca

Sandra Loucks Campbell, Renison University College at the University of Waterloo

Angela Hovey, Vice President, Services and Operations, Pace Consulting Group, Pace

Homecare, Pace Physiotherapy, Waterloo, Ontario.

(c) (1)

This work is licensed under a Creative Commons Attribution 3.0 License. 